IOSR Journal of Pharmacy

e-ISSN: 2250-3013, p-ISSN: 2319-4219, www.iosrphr.org

Volume 2 Issue 6 || || Nov-Dec. 2012 || | PP.54-60

\title{
Screening of antioxidant activity of lichens Parmotrema reticulatum and Usnea sp. from Darjeeling hills, India
}

\author{
${ }^{1}$ Binod Chandra Sharma, Sujata Kalikotay ${ }^{2}$ \\ ${ }^{1,2}$ P.G. Department of Botany, Darjeeling Government College, Darjeeling -734101, India
}

\begin{abstract}
Till date many plants have been screened for their antioxidant activity. Oxidative stress can lead to the production of free radicals which may cause many degenerative diseases. These free radicals can be eliminated with the help of antioxidants which may be of a natural origin. The aim of this study was to examine the antioxidant activity of two common lichens namely Parmotrema reticulatum and Usnea sp from Darjeeling hills. The antioxidant assay of different concentration of ethanolic and methanolic extracts of lichens was determined with respect to five parameters $i$. e., DPPH radical scavenging activity, total antioxidant activity, reducing power ability, flavonoid and phenolic content. The DPPH radical scavenging ranged from $10 \%$ to $31.5 \%$ for methanol extracts of Parmotrema reticulatum and Usnea sp respectively and for reducing power measured values of absorbance varied from 0.376 to 0.514 . In addition, total phenolic content of the extracts were high and total flavonoids content was moderate. Tested lichen species were found to possess considerable antioxidant activities and could be evaluated as good natural sources of antioxidants.
\end{abstract}

Keywords-Antioxidants, Parmotrema reticulatum, Usnea sp., Darjeeling.

\section{INTRODUCTION}

Free radicals which have one or more unpaired electrons are produced in normal or pathological cell metabolism. Reactive oxygen species (ROS) react easily with free radicals to become radicals themselves. ROS are various forms of activated oxygen, which include free radicals such as superoxide anion radicals $\left(\mathrm{O}^{-2}\right)$ and hydroxyl radicals $\left(\mathrm{OH}^{-1}\right)$, as well as non-free radical species $\left(\mathrm{H}_{2} \mathrm{O}_{2}\right)$ and the singlet oxygen $\left({ }^{1} \mathrm{O}_{2}\right)[1,2,3,4]$. Also, excessive generation of ROS, induced by various stimuli and which exceed the antioxidant capacity of the organism, leads to a variety of pathophysiological processes such as inflammation, diabetes, genotoxicity, and cancer $[5,6,7]$. Exogenous sources of free radicals include tobacco smoke, ionizing radiation, certain pollutants, organic solvents, and pesticides $[3,8,9,10]$. The most effective way to eliminate free radicals which cause the oxidative stress is with the help of antioxidants.

Antioxidants, both exogenous and endogenous, whether synthetic or natural, can be effective in preventing free radical formation by scavenging and suppressing such disorders [11, 12-14]. Currently, there is a growing interest toward natural antioxidants of herbal resources [10-12]. Epidemiological and in vitro studies on medicinal plants and vegetables strongly supported this idea that plant constituents with antioxidant activity are capable of exerting protective effects against oxidative stress in biological systems [13-16].

Lichens are the symbiotic organisms including a fungal partner and an algal partner and are known to have therapeutic effects on various diseases in folk medicine of many countries. Recently, much attention has been paid to lichens as resources of natural antioxidants. Scientist already investigated the antioxidant activity of some species of lichens, such as Bryoria fuscescens, Cetraria islandica, Dermatocarpon intestiniformis, Parmelia saxatilis, Peltigera rufescens, Platismatia glauca, Ramalina pollinaria, R. polymorph, Umbilicaria nylanderiana, Usnea ghattenis, and U. longissima and some of them have very good antioxidant activity [17, $18,19,20]$.

India is a rich centre of lichens diversity, contributing nearly $15 \%$ of the 13500 species of lichens so far recorded [21]. Darjeeling hills, one of the picturesque hill stations of Eastern Himalayas is situated at coordinates $27{ }^{\circ} 13^{\prime} \mathrm{N}$ to $26^{\circ} 27^{\prime} \mathrm{N}$ and $88^{\circ} 53^{\prime} \mathrm{E}$ to $87^{\circ} 58^{\prime} \mathrm{E}$. It has an area of $3,149 \mathrm{sq} \mathrm{km}$. Its annual mean maximum temperature is $14.9^{\circ} \mathrm{C}$ and annual mean minimum temperature is $8.9^{\circ} \mathrm{C}$ and average annual rainfall is $3092 \mathrm{~mm}$.

Lichens occur in abundance in Darjeeling Hills of West Bengal, India. Hence this work was set out in order to screen the antioxidant activity of two common lichen species namely Parmotrema reticulatum and Usnea sp of Darjeeling hills. 


\section{MATERIALS AND METHODS}

\subsection{Collection and identification of lichen materials:}

The lichen specimens was collected from the trees growing around Darjeeling town and characterised with the help of their morphology, anatomy, colour reaction, thin layer chromatography and identified from National Botanical Research Institute, Lucknow as Parmotrema reticulatum 08-0017193 (LWG) and Usnea sp 09-0017196 (LWG). Specimen samples namely SK1 and SK2 are preserved in the Herbarium of Darjeeling Government College, Darjeeling.

\subsection{Extract preparation:}

Lichen specimens were air dried at room temperature to constant weights. The dried plant materials were ground separately to powder. Ten grams of each powdered lichen material were extracted in methanol and ethanol (50 ml each) by shaking for 48 hours in shaking incubator (Orbital Shaking Incubator MSW232, Macro Scientific Works, New Delhi, INDIA). Each extract was filtered with Tarsons Nylon Membrane Filter 66, Riviera, Kolkata of pore size $450 \mathrm{~nm}$. Each filtrate was evaporated and residue obtained stored in refrigerator.

\subsection{Chemicals used}

1,1-Diphenyl-2-picrylhydrazyl (DPPH), ascorbic acid, aluminum nitrate, potassium acetate, quercetin, Folin-Ciocalteus's phenol reagent, sodium carbonate, tannic acid, potassium ferricyanide, phosphate buffer, trichloroacetic acid, ferric chloride, butylated hydroxytoluene (BHT), sodium phosphate, ammonium molybdate, $\alpha$-tocopherol were obtained HiMedia Laboratories, Mumbai, INDIA. All the chemicals used including the solvents were of analytical grade.

\subsection{DPPH radical scavenging assay}

The effect of the extracts on DPPH radical was estimated using the method of Liyana- Pathiranan and Shahidi [26]. A solution of $0.135 \mathrm{mM}$ DPPH in methanol was prepared and $1.0 \mathrm{ml}$ of this solution was mixed with $1.0 \mathrm{ml}$ of extract in methanol containing $0.02-0.1 \mathrm{mg}$ of the extract. The reaction mixture left in the dark at room temperature for $30 \mathrm{~min}$. The absorbance of the mixture was measured spectrophotometrically at $517 \mathrm{~nm}$. Ascorbic acid was used as reference. The ability to scavenge DPPH radical was calculated by the following equation: DPPH radical scavenging activity $(\%)=[($ Abs control - Abs sample $)] /($ Abs control $)$ x 100 where Abs control is the absorbance of DPPH radical + methanol or ethanol; Abs sample is the absorbance of DPPH radical + sample extract/standard.

\subsection{Determination of ferric reducing antioxidant power (FRAP)}

Reducing power of both extracts of the lichen specimens were measured by method of Oyaizu [28] with slight modifications. According to this method the reduction of $\mathrm{Fe}^{3+}$ to $\mathrm{Fe}^{2+}$ was determined by measuring absorbance of the Perl's Prussian blue complex. This method is based on the reduction of $\left(\mathrm{Fe}^{3+}\right)$ ferricyanide in stoichiometric excess relative to the antioxidants. For this purpose, different concentrations $(25,50,100$ and 200 $\mu \mathrm{g} / \mathrm{mL}$ ) of lichen extracts in ethanol and methanol, and standard antioxidants ( BHT) was added to the each tube, volumes were adjusted with distilled water to $0.75 \mathrm{~mL}$, separately. Then, they were mixed with $1 \mathrm{ml}$ of $200 \mathrm{mM}$ sodium phosphate buffer $(\mathrm{pH} 6.6)$ and $1 \mathrm{ml}(1 \%)$ of potassium ferricyanide $\left[\mathrm{K}_{3} \mathrm{Fe}(\mathrm{CN})_{6}\right]$. After $20 \mathrm{~min}$ of incubation at $50^{\circ} \mathrm{C}$, the reaction mixtures were acidified with $1 \mathrm{ml}$ of trichloroacetic acid (10\%). Finally, 0.25 $\mathrm{ml}$ of $\mathrm{FeCl}_{3}(0.1 \%)$ was added to this solution. Distilled water was used as control. Absorbance of these mixtures was measured at $700 \mathrm{~nm}$ using spectrophotometer [29]. Decreased absorbance indicates ferric reducing power capability of sample [30].

\subsection{Determination of total phenolics}

Using modified Folin-Ciocalteu method [24], total phenolic contents of the extracts were determined. An aliquot of the extract was mixed with $5 \mathrm{ml}$ Folin-Ciocalteu reagent (previously diluted with water at 1:10 $\mathrm{v} / \mathrm{v})$ and $4 \mathrm{ml}(75 \mathrm{~g} / \mathrm{l})$ of sodium carbonate. The tubes were vortexed for $15 \mathrm{sec}$ and allowed to stand for $30 \mathrm{~min}$ at $40^{\circ} \mathrm{C}$ for color development. Absorbance was then measured at $765 \mathrm{~nm}$ in a spectrophotometer (UV-1700 PharmaSpec UV-VS Spectrophotometer, Shimadzu, Japan). Samples of extracts were evaluated at a final concentration of $0.1 \mathrm{mg} / \mathrm{ml}$. Total phenolic content were expressed as $\mathrm{mg} / \mathrm{g}$ tannic acid equivalent using the equation based on the calibration curve: $\mathrm{y}=.007 \mathrm{x}-0.186, \mathrm{R} 2=0.938$, where $\mathrm{x}$ was the absorbance and $\mathrm{y}$ was the tannic acid equivalent $(\mathrm{mg} / \mathrm{g})$.

\subsection{Determination of total flavonoids}

Estimation of the total flavonoids in the plant extracts was carried out using the method of Ordon Ez et al [25]. To $0.5 \mathrm{ml}$ of sample, $0.5 \mathrm{ml}$ of $2 \% \mathrm{AlCl}_{3}$ ethanol solution was added. After one hour at room temperature, the absorbance was measured at $420 \mathrm{~nm}$. A yellow colour indicated the presence of flavonoid. Extract samples were evaluated at a final concentration of $0.1 \mathrm{mg} / \mathrm{ml}$. Total flavonoid content was calculated as quercetin $(\mathrm{mg} / \mathrm{g})$ using the following equation based on the calibration curve: $\mathrm{y}=0.356 \mathrm{x}-0.461, \mathrm{R} 2=0.697$, where $\mathrm{x}$ was the absorbance and was the quercetin equivalent $(\mathrm{mg} / \mathrm{g})$.

\subsection{Determination of total antioxidant capacity}

The total antioxidant capacity of lichen extracts, and its different fractions was evaluated by the method of Prieto et al. [27]. An aliquot of $0.1 \mathrm{ml}$ of sample $(100 \mu \mathrm{g})$ solution was combined with $1 \mathrm{ml}$ of reagent $(0.6 \mathrm{M}$ 
sulfuric acid, $28 \mathrm{mM}$ sodium phosphate and $4 \mathrm{mM}$ ammonium molybdate). The tubes were capped and incubated in a boiling water bath at $95^{\circ} \mathrm{C}$ for $90 \mathrm{~min}$. After the samples had cooled to room temperature, the absorbance of the aqueous solution of each was measured at $695 \mathrm{~nm}$ against blank in a spectrophotometer (UV1700 PharmaSpec UV-VS spectrophotometer, Shimadzu, Japan). A typical blank solution contained $1 \mathrm{ml}$ of reagent solution and the appropriate volume of the same solvent used for the sample and it was incubated under same conditions as rest of the sample. For samples of unknown composition, antioxidant capacity was expressed as equivalents of $\alpha$-tocopherol ( $\mathrm{mg} / \mathrm{g}$ ).

\subsection{Statistical analysis}

All analysis was done in triplicates. Data were analyzed in Microsoft EXCEL-2007 by taking triplicates and thus mean and Standard Deviation (SD) obtained.

\section{RESULTS AND DISCUSSIONS}

\subsection{DPPH Radical Scavenging Activity}

Free radicals contribute to more than one hundred disorders in humans including atherosclerosis, arthritis, ischemia and reperfusion injury of many tissues, central nervous system injury, gastritis, cancer and AIDS [26, 29]. The synthetic antioxidants like BHA, BHT, gallic acid esters etc., have been suspected to cause or prompt negative health effects. Strong restrictions have been placed on their application [30, 31]. In recent years much attention has been devoted to natural antioxidant and their association with health benefits [32]. The antioxidant activity of putative antioxidants have been attributed to various mechanisms, among which are prevention of chain initiation, binding of transition metal ion catalysts, decomposition of peroxides, prevention of continued hydrogen abstraction, reductive capacity and radical scavenging [33]. Numerous antioxidant methods and modifications have been proposed to evaluate antioxidant activity and to explain how antioxidants function. Of these, total antioxidant activity, reducing power, DPPH assay, metal chelating, ROS quenching assays are commonly used for evaluation of antioxidant activities of extracts [34, 35].

Table 1. DPPH radical scavenging of the ethanol and methanol extracts of the lichen Parmotrema reticulatum, Usnea sp and ascorbic acid.

\begin{tabular}{|c|c|c|c|}
\hline \multirow[t]{6}{*}{ Ascorbic acid } & Concentration ( $\mathrm{\mu g} / \mathrm{ml})$ & OD517 nm & Inhibition \% \\
\hline & control & $0.750 \pm 0.0057$ & - \\
\hline & 25 & $0.638 \pm 0.0057$ & 16 \\
\hline & 50 & $0.562 \pm 0.0057$ & 26 \\
\hline & 100 & $0.481 \pm 0.0057$ & 36.7 \\
\hline & 200 & $0.231 \pm 0.0057$ & 69.6 \\
\hline \multirow[t]{5}{*}{ Usnea sp (M) } & control & $0.76 \pm .0 .057$ & - \\
\hline & 25 & $0.63 \pm 0.0057$ & 17 \\
\hline & 50 & $0.61 \pm 0.0057$ & 19.4 \\
\hline & 100 & $0.57 \pm 0.0057$ & 24.4 \\
\hline & 200 & $0.52 \pm 0.0057$ & 31.5 \\
\hline \multirow[t]{5}{*}{ Usnea sp (E) } & control & $0.82 \pm 0.0057$ & - \\
\hline & 25 & $0.71 \pm 0.001$ & 12.8 \\
\hline & 50 & $0.62 \pm 0.0057$ & 24.3 \\
\hline & 100 & $0.51 \pm 0.00057$ & 37.1 \\
\hline & 200 & $0.41 \pm 0.0057$ & 49.7 \\
\hline \multirow{5}{*}{$\begin{array}{l}\text { Parmotrema } \\
\text { reticulatum (E) }\end{array}$} & control & $.43 \pm .00057$ & \\
\hline & 25 & $0.363 \pm 0.00057$ & 16.5 \\
\hline & 50 & $0.359 \pm 0.00015$ & 17 \\
\hline & 100 & $0.356 \pm 0.002$ & 18.1 \\
\hline & 200 & $0.351 \pm 0.002$ & 19.3 \\
\hline \multirow{5}{*}{$\begin{array}{l}\text { Parmotrema } \\
\text { reticulatum (M) }\end{array}$} & control & $0.796 \pm .0005$ & \\
\hline & 25 & $.716 \pm .0005$ & 10.1 \\
\hline & 50 & $.667 \pm .0005$ & 15.5 \\
\hline & 100 & $.619 \pm 0.321$ & 21.6 \\
\hline & 200 & $.611 \pm .0011$ & 22.6 \\
\hline
\end{tabular}

Data represented as mean $\pm \mathrm{SD}$ of three independent readings

E- Ethanolic extract; M- Methanolic extract 
The change in absorbance produced by reduced DPPH was used to evaluate the ability of test compounds to act as free radical scavengers. It was observed (Table:1) that methanolic extracts of Parmotrema reticulatum and Usnea sp showed potent radical scavenging activity with IC50 value of $4.39 \mu \mathrm{g} / \mathrm{ml}$ and 3.21 $\mu \mathrm{g} / \mathrm{ml}$ respectively, the IC50 value of ethanolic extracts of Usnea sp and Parmotrema reticulatum are $4.023 \mu \mathrm{g} / \mathrm{ml}$ and $2.95 \mu \mathrm{g} / \mathrm{ml}$ respectively. Removal of free radical increased by 10.1 to $49.7 \%$ in accordance with the increase of the concentrations of the extract from $25 \mu \mathrm{g} / \mathrm{ml}$ to $200 \mu \mathrm{g} / \mathrm{ml}$, compared to the negative control and moreover, the scavenging ability of the extract was as moderately less as that of ascorbic acid at all the concentrations tested. Significant correlation was found between the free radical scavenging activity and the concentration of lichen extract or the compound used as positive control. The DPPH assay is a widely used method to evaluate antioxidant activities in a relatively short time compared to other methods [36]. The reduction capability on the DPPH radical is determined by the decrease in its absorbance at $517 \mathrm{~nm}$. The decrease in absorbance of DPPH radical caused by antioxidants is due to the reaction between antioxidant molecules and radical, which results in the scavenging of the radical by hydrogen donation. This is visualized as a discoloration from purple to yellow. Hence, DPPH is usually used as a substrate to evaluate antioxidant activity [37, 38]. In this study, a significant decrease in the concentration of DPPH radical due to the scavenging ability of the extract was observed. Though the DPPH radical scavenging abilities of the lichen extracts was less than that of standard, the study showed that the extracts has proton-donating ability and could serve as a natural antioxidant.

\subsection{Reducing power assays}

Reduction capacity of a compound may serve as a significant indicator of its potential antioxidant activity. Antioxidant compounds are able to donate electrons to reactive radicals, reducing them into more stable and unreactive species [18, 19].The reducing power of the extracts was compared with standard Butylatedhydroxytoluene (BHT) and it increased with increasing concentration of the extracts. The methanolic extracts of Parmotrema reticulatum showed high reducing ability with absorbance of 0.491 at concentration of $300 \mu \mathrm{g} / \mathrm{ml}$ and absorbance of methanolic extracts of Usnea sp was highest as 0.514 at $300 \mu \mathrm{g} / \mathrm{ml}$. Antioxidant compounds cause the reduction of ferric $\left(\mathrm{Fe}^{3+}\right)$ form to the ferrous $\left(\mathrm{Fe}^{2+}\right)$ form because of their reductive capabilities. Prussian blue coloured complex formed by adding $\mathrm{FeCl}_{3}$ to the ferrous $\left(\mathrm{Fe}^{2+}\right)$ form. Therefore, reduction can be determined by measuring the formation of Perl's Prussian blue at $700 \mathrm{~nm}[20,30]$. In this assay, yellow colour of the test solution changes to green or blue colour depending on the reducing power of antioxidant samples. A higher absorbance indicates a higher ferric reducing power.

Table 2: Reducing power of extracts of lichen Parmotrema reticulatum, Usnea sp and BHT.

\begin{tabular}{|lll|}
\hline BHT & Concentration in $\mu \mathrm{g} / \mathrm{ml}$ & $0 . \mathrm{D} 700 \mathrm{~nm}$ \\
\hline & 50 & $.555 \pm .002$ \\
\hline & 100 & $.751 \pm .0005$ \\
\hline & 200 & $.815 \pm .001$ \\
\hline & 300 & $.893 \pm .004$ \\
\hline & 50 & $.413 \pm .001$ \\
\hline & 100 & $.421 \pm .001$ \\
\hline Usnea sp (M) & 200 & $.425 \pm .002$ \\
\hline & 300 & $.434 \pm .002$ \\
\hline & 50 & $.402 \pm .001$ \\
\hline & 100 & $.411 \pm .001$ \\
\hline Parmotrema reticulatum $\mathbf{( E )}$ & 200 & $.502 \pm .003$ \\
\hline & 300 & $.514 \pm .003$ \\
\hline & 50 & $.195 \pm .003$ \\
\hline & 200 & $.205 \pm .003$ \\
\hline Parmotrema reticulatum(M) & 50 & $.342 \pm .003$ \\
\hline & 100 & $.376 \pm .002$ \\
\hline & 200 & $.363 \pm .001$ \\
\hline & 300 & $.394 \pm .002$ \\
\hline
\end{tabular}

Data represented as mean $\pm \mathrm{SD}$ of three independent readings

E- Ethanolic extract; M- Methanolic extract 
Screening of Antioxidant Activity of Lichens Parmotrema reticulatum and...

3.3 Total phenolic and flavonoids contents

Table 3: Total phenolic and flavonoid content of lichen Parmotrema reticulatum and Usnea sp

\begin{tabular}{|lll|}
$\begin{array}{l}\text { Lichen extracts } \\
\text { equivalent/mg) }\end{array}$ & $\begin{array}{c}\text { Total phenolic content } \\
\text { tannic acid equivalent/mg) }\end{array}$ & $\begin{array}{c}\text { Total flavonoid content } \\
\text { (ug quercetin }\end{array}$ \\
\hline Parmotrema reticulatum $(\mathbf{E})$ & $\mathbf{1 1 3} \pm \mathbf{1}$ & $\mathbf{1 . 4 2} \pm \mathbf{0 . 0 1}$ \\
\hline Parmotrema reticulatum $(\mathbf{M})$ & $\mathbf{1 5 1} \pm \mathbf{0 . 5 7 7}$ & $\mathbf{1 . 3 8} \pm \mathbf{0 . 0 0 5 7}$ \\
\hline Usnea $\mathbf{s p}(\mathbf{E})$ & $\mathbf{1 1 0} \pm \mathbf{0 . 5 7 7}$ & $\mathbf{1 . 4 9 8} \pm \mathbf{0 . 0 0 1}$ \\
\hline Usnea $\operatorname{sp}(\mathbf{M})$ & $\mathbf{1 4 8} \pm \mathbf{0 . 5 7 7}$ & $\mathbf{1 . 5 4 3} \pm \mathbf{0 . 0 0 5 7}$ \\
\hline
\end{tabular}

Data represented as mean \pm SD of three independent readings

E- Ethanolic extract; M- Methanolic extract

Results obtained in the present study revealed that the level of these phenolic compounds in the ethanol extracts of the Parmotrema reticulatum and Usnea sp were considerable. The phenolic content of methanolic extracts of Parmotrema reticulatum and Usnea sp are $151 \mu \mathrm{g}$ and $148 \mu \mathrm{g}$ tannic acid equivalent. Polyphenolic compounds are known to have antioxidant activity and it is likely that the activity of the extracts is due to these compounds [31, 32]. This activity is believed to be mainly due to their redox properties, which play an important role in adsorbing and neutralizing free radicals, quenching singlet and triplet oxygen, or decomposing peroxides [33]. In fact, many medicinal plants contain large amounts of antioxidants such as polyphenols. Many of these phytochemicals possess significant antioxidant capacities that are associated with lower occurrence rates of several human diseases [34, 35]. Phenols are very important constituents because of their scavenging ability due to the presence of hydroxyl groups [39].

Flavonoids are wide group of natural compounds and also the most important natural phenolics. These compounds have a large number of biological and chemical activities including radical scavenging properties [40]. The amount of flavonoids in the lichen extracts were very less such as $1.54 \mu \mathrm{g}$ and $1.49 \mu \mathrm{g}$ for ethanolic and methanolic extracts of Usnea sp respectively

\subsection{Total antioxidant activity}

The phosphomolybdenum method has been used to investigate the total antioxidant capacity of the extracts. This method is quantitative, since the total antioxidant capacity is expressed as $\alpha$ - tocopherol equivalents. The ethanolic and methanolic extracts of Parmotrema reticulatum contained 0.781 and $1.58 \mu \mathrm{g}$ vitamin $\mathrm{E}$ equivalent $/ \mathrm{mg}$ and that of Usnea sp was $2.025 \mu \mathrm{g}$ and $0.690 \mu \mathrm{g}$ vitamin $\mathrm{E}$ equivalent $/ \mathrm{mg}$ respectively. In fact, many medicinal plants contain large amounts of antioxidants such as polyphenols. Many of these phytochemicals possess significant antioxidant capacities that are associated with lower occurrence rates of several human diseases [ 34,35].

Table 4. Total antioxidant activity of lichen Parmotrema reticulatum and Usnea sp.

\begin{tabular}{lc} 
Lichen extract & Total antioxidant activity $(\mu \mathrm{g}$ vitamin E equivalent $/ \mathrm{mg})$ \\
Parmotrema reticulatum $(\mathrm{E})$ & $\mathbf{0 . 7 8 1} \pm .00057$ \\
\hline Parmotrema reticulatum $(\mathrm{M})$ & $\mathbf{1 . 5 8} \pm .00577$ \\
\hline Usnea $\operatorname{sp}(\mathrm{E})$ & $\mathbf{2 . 0 2 5} \pm .001$ \\
\hline Usnea $\operatorname{sp}(\mathrm{M})$ & $\mathbf{0 . 6 9 0} \pm .001$
\end{tabular}

Data represented as mean $\pm \mathrm{SD}$ of three independent readings

E- Ethanolic extract; M- Methanolic extract

\section{CONCLUSION}

The investigation for bioactive compounds from natural resources to improve pharmaceutical, cosmetic and agriculture applications is extremely advancing till today. The lichen compounds are also being investigated for its phytochemical properties. Peroxidation (auto-oxidation) of lipids exposed to oxygen is responsible not only for deterioration of foods (rancidity) but also damage to tissue in vivo, where it may be a cause of cancer, inflammatory disease, ageing etc. Thus there is an increase in demand for drugs of natural origin for healing several diseases. On the basis of the results, it can be concluded that tested lichen extracts show a strong antioxidant activity in vitro. The intensity of antioxidant activity depended on the tested lichen species and the solvent that used for extraction. Different antioxidant activities of different solvents depend on their different capabilities to extract bioactive substances [41]. Ethanolic and methanolic extracts of Parmotrema reticulatum and Usnea sp possessed potent antioxidant activity and DPPH radical scavenging activity. Presence of an appreciable amount of phenol and flavonoid content could suggest for the use of these extracts as natural source of antioxidants. Further, the bioactive substances from these samples are under investigation. 


\section{ACKNOWLEDGEMENTS}

We are grateful to the University Grant Commission for providing financial assistance to Miss Sujata Kalikotay under Rajiv Gandhi National Fellowship Scheme. We acknowledge Department of Science and Technology, Govt. of India for providing instrumentation facility to the department under DST-FIST scheme.

\section{REFERENCES}

[1]. B. Halliwell, How to characterize an antioxidant: an update. Bioch. Soc. Sym., 1995, 61, 85-91.

[2]. G.L. Squadriato, W.A. Peyor, Oxidative chemistry of nitric oxide: the role of superoxide, peroxynitrite, and carbon dioxide, Free Radical. Biol. Med., 1998, 25, 392-403.

[3]. A. Yildrim, M. Oktay and V. Bilaloglu, The antioxidant activity of the leaves of Cydonia vulgaris. Turkish J. Med. Sc., 2001, 31: 23-27.

[4]. Gulcin, M. Okay, I. O. Kufrevioglu, A. Aslan, Determination of antioxidant activity of Lichen Cetraria islandica (L) Ach. J. Ethnopharmacol., 2002, 79,325-329.

[5]. A.P Kourounakis, D. Galanakis, K. Tsiakitzis, Synthesis and pharmacological evaluation of novel derivatives of anti-inflammatory drugs with increased antioxidant and anti-inflammatory activities. Drug Dev. Res., 1991, 47(1), 9-16.

[6]. I. Gulcin, M.E Buyukokuroglu, M. Oktay, I.O Kufreviogl, On the in vitro antioxidant properties of melatonin. J. Pineal Res., 2002, 3, 167-171.

[7]. I. Gulcin, M.E Buyukokuroglu, M. Oktay, and I.O Kufrevioglu, Antioxidant and analgesic activities of turpentine of Pinus nigra Arn. Subsp. Pallsiana (Lamb.) Holmboe. J Ethnopharmacol., 2003, 86, 51-58.

[8]. K.J.A Davies, Oxidative stress: the paradox of aerobic life, Bioch. Soc. Sym. 1993, 61, 1-34.

[9]. F.E Robinson, S.R.J Maxwell, and G.H.G Thorpe, An investigation of the antioxidant activity of black tea using enhanced chemiluminescence. Free Radical Res., 1997, 26, 291-302.

[10]. M.E Buyukokuroglu , I Gulcin , M .Oktay, O.I Kufrevioglu , In vitro antioxidant properties of dantrolene sodium. Pharmacolog. Res., 2001, 44, 1199-2000.

[11]. B. Halliwell, The antioxidant paradox. Lancet .2005, 355, 1179-1180.

[12]. S.R.J Maxwell, Prospects for the use of antioxidant therapies. Drugs, 1995, 49,: 345-361.

[13]. G.Cao , E.R Sofic and R.L Prior, Antioxidant capacity of tea and common vegetables. J. Agric. Food Chem. 1996;44: 3426-3431

[14]. M. Cesquini , M.A. Torsoni , G.R Stoppa and S.Hogo, t- BuOH-induced oxidative damage in sickle red blood cells and the role of flavonoids. Biomed. Pharmacother., 2003, 57, 124-129.

[15]. M.A Eastwood, Interaction of dietary antioxidants in vivo: how fruit and vegetables prevent diseases? Q. J.Med., $1999,52,527-530$

[16]. G. Block and B Patterson, Fruits, vegetables and cancer prevention: a review of the epidemiological evidence.Nutr. Cancer, 1992,18, 1-29.

[17]. B.C. Behera, N. Verma, A. Sonone and U. Makhija, Determination of antioxidative potential of lichen Usnea ghattensis in vitro, LWT - Food Sci. Technol., 2006,39, 80-85.

[18]. [18] M.Gulluce, A. Aslan, M Sokmen, F Sahin, A Adiguzel et. al., Screening the antioxidant and antimicrobial properties of the lichens Parmelia saxatilis, Platismatia glauca, Ramalina pollinaria, Ramalina polymorpha and Umbilicaria nylanderiana. Phytomedicine. 2006,13, 515-521.

[19]. M. Halici , F. Odabasoglu , H. Suleyman, A .Cakir , A. Asland and Y. Bayir, Effects of water extract of Usnea logissima on antioxidant enzyme activity and mucosal damage caused by indomethacin in rats. Phytomedicine $1995,12,656-662$.

[20]. F. Odabasoglu, A.Asland, A.Cakir, H. Suleyman, Y. Karagoz et. al, Antioxidant activity, reducing power and total phenolic contents of some lichen species. Fitoterapia, 200 ,76, 216-219.

[21]. H.R. Negi, On the patterns of abundance and diversity of macrolichens of Chopta-Tunganath in the Garhwal Himalayas. J. Biosci., 2000 , 25, 367-378.

[22]. D.D Awasthi, A key to macrolichens of India and Nepal. Journal of Hattori Botanical Laboratory, 65, 1988, $207-$ 302.

[23]. A Key to the Microlichens of India, Nepal and Sri Lanka. By D. D. Awasthi. [Bibliotheca Lichenologica, No. 40]. Berlin \& Stuttgart: J. Cramer., 1991, $332+2$ [Addendum]

[24]. K. Wolfe, X.Wu, and R.H Liu, Antioxidant activity of apple peels. J. Agric. Food Chem., 2003,5, 609-614.

[25]. A. A. L. Ordon Ez., J. D Gomez, M.A Vattuone, and M.A Isla. Antioxidant activities of Sechium edule (Jacq.) Swart extracts. Food Chem., 2006, 47, 452-458.

[26]. C.M.F. Liyana-Pathiranan Shahidi, Antioxidant activity of commercial soft and hard wheat (Triticum aestivum L) as affected by gastric pH conditions. J. Agric. Food Chem., 2005, 53, 2433-2440.

[27]. P. Prieto, M. Pineda and M. Aguilar, Spectrophotometric quantitation of antioxidant capacity through the formation of a phosphomolybdenum complex: specific application to the determination of vitamin E. Anal. Biochem., 1999,269,337-341.

[28]. M.Oyaizu, Studies on product of browning reaction prepared from glucose amine. J. Nut., 1986, 44, 307-315.

[29]. I. Gülçin, D.Berashvili, A Gepdiremen, Antiradical and antioxidant activity of total anthocyanins from Perilla pankinensis decne. J. Ethnopharmacol, 2005,101(b), 287-293.

[30]. I.Gülçin Antioxidant and antiradical activities of L-Carnitine. Life Sci., 2006, 78, 803-811. 
[31]. T. Okudu, T. Yoshida and T.Hatano, Food phytochemicals for cancer prevention II. In C T Ho, T. Osawa , M.THuang and R.T Rosen (Eds.). Chemistry and antioxidative effects of phenolic compounds from licorice, tea and Compositae and Labiateae herbs, Washington, DC: American Chemical Society, 1994, 132-143.

[32]. B. Tepe, M. Sokmen, H.A Akpulat and A Sokmen. Screening of the antioxidant potentials of six Salvia species from Turkey. Food Chem., 2006, 9, 200-204.

[33]. W. Zheng and S.Y Wang, Antioxidant activity and phenolic compounds in selected herbs. J. Agric. Food Chem., 2001, 49(11), 5165-5170.

[34]. K. J. Anderson, S.S Teuber, A.Gobeille, P.Cremin , A.L. Waterhouse, F.M. Steinberg, Walnut polyphenolics inhibit in vitro human plasma and LDL oxidation. Biochemical and molecular action of nutrients. J. Nutr., 2001, $131,2837-2842$.

[35]. A. Djeridane, M. Yousfi, B.Nadjemi, D. Boutassouma, P. Stocker and N. Vidal, Antioxidant activity of some Algerian medicinal plants extracts containing phenolic compounds. Food Chem., 2006, 9,654-660.

[36]. J.R. Soares, T.C.P. Dins, A.P. Cunha, and L.M. Ameida, Free Rad. Res., 1997, 26, 469-478.

[37]. P.D. Duh , Y.Y. Tu and G.C. Yen . Antioxidant Activity of Water Extract of Harng Jyur (Chrysanthemum morifolium Ramat) Lebensmittel-Wissenchaft und Technologie., 1999,32,269-277.

[38]. L.W. Chang, W.J. Yen, S.C. Huang and P.D. Duh. Food Chem., 2002, 78, 347-354.

[39]. T. Hatano ,R. Edamatsu, A.Mori ,Y. Fujita and E. Yasuhara, Chem Pharm Bull.1989, 37, 2016-2021.

[40]. M.F.A. Ghafar, P.K. Nagendra, K.K. Weng and A.Ismail, Flavonoid, hesperidine, total phenolic contents and antioxidant activities from Citrus species. Afr. J. Biotechno.,2010, 9: 326-330.

[41]. B.C. Behera, N.Verma, A. Sonone and U. Makhija, Antioxidant and antibacterial activities of lichen Usnea ghattensis in vitro. Biotechnol. Lett., 2005, 27, 991-995. 